\title{
RESPONSE TO BLEOMYCIN OF ESCHERICHIA COLI MUTANTS DEFICIENT IN DNA REPAIR
}

\author{
Kazuo Yamamoto and Franklin Hutchinson \\ Department of Molecular Biophysics and Biochemistry \\ Yale University, New Haven, Connecticut 06520, U.S.A. \\ (Received for publication August 9, 1979)
}

\begin{abstract}
The effect of bleomycin on the colony forming ability of Escherichia coli K12 strains in exponential growth at $37^{\circ} \mathrm{C}$ was not affected by introducing recAl3, lexAl, polAI and uvrA6 mutations. For cells starved for amino acids, wild type strains became ten-fold more resistant to bleomycin, but again introducing lexAl, polAl and $u v r A 6$ strains did not change the effect on colony forming ability; however, starved recA13 cells were now four-fold more sensitive. Strains with recA13, lexA1 and polA1 mutations were always more sensitive than wild type to gamma rays under the same conditions as used for the bleomycin treatment. It is suggested that bleomycin-induced lesions may be concentrated in that part of the bacterial genomes at the cell wall, near the replication forks.
\end{abstract}

The antitumor drug, bleomycin, produces effects on living cells which resemble those produced by ionizing radiations: loss of ability to form colonies for mammalian and bacterial cells ${ }^{1}$, production of chromosomal aberrations ${ }^{2)}$, degradation of intracellular DNA to acid-soluble form ${ }^{3)}$, inhibition of DNA synthesis ${ }^{4)}$, release of DNA from a complex with membrane ${ }^{5)}$, induction of prophages in bacteria $^{6)}$, and induction of synthesis of recA protein in Escherichia coli cells ${ }^{7)}$. On DNA in solution, bleomycin produces single-strand ${ }^{8)}$ and double-strand breaks ${ }^{4,9)}$, as do ionizing radiations. Bleomycin releases bases from the $\mathrm{DNA}^{10,11)}$, and so do ionizing radiations ${ }^{12)}$. The similarity of biological effects may be a consequence of similarities in the DNA lesions. However, it has been reported that bleomycin reduces the colony forming ability of $l e x A^{13)}$ and polA1 $1^{14)}$ E. coli cells in exponential growth at $37^{\circ} \mathrm{C}$ to the same level as for wild type cells, although both mutants are more sensitive to X-rays. E. coli rec A cells, quite sensitive to X-rays, have been reported to be more sensitive to phleomycin ${ }^{14}$, or equally sensitive to bleomycin ${ }^{13}$.

The experiments reported in this paper show that the colony forming ability of E. coli cells depends strongly on the conditions of treatment with bleomycin. RecA mutants are more sensitive than wild type under some conditions, and have the same sensitivity under other conditions. LexA, polA and $u v r A$ cells respond to bleomycin in the same way as do wild type strains under the conditions used.

\section{Materials and Methods}

\section{Chemicals}

Bleomycin A2 (Lot 33), the generous gift of the Developmental Therapeutics Program, Chemotherapy, N.C.I., was dissolved in double distilled water at $2 \mathrm{mg} / \mathrm{ml}$ and kept frozen at $-20^{\circ} \mathrm{C}$ in small quantities until used. All other chemicals were obtained from commercial sources.

Bacterial Strains

Those used, and the relevant genotypes, were: E. coli $\mathrm{K} 12 \mathrm{AB} 2497 \mathrm{rec}^{+} \mathrm{arg}^{-}$his $^{-}$and its almost isogenic derivatives AB2487 recA13 $\mathrm{arg}^{-}$his $^{-}, \mathrm{AB} 2500 \mathrm{uvrA6} \mathrm{arg}^{-} \mathrm{his}^{-}$(all from P. Howard-Flanders); 


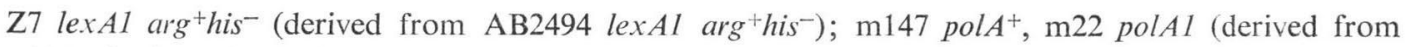
P3478, both strains a gift of R. Moses) have an unknown amino acid requirement.

Culture Media

$\mathrm{K}$ medium (M9 buffer $+1 \%$ glucose + decolorized, vitamin-free $1 \%$ casamino acids) containing $10 \mu \mathrm{g} / \mathrm{ml}$ thymine were used for cell growth. M9 buffer used in this work was $18.7 \mathrm{mM} \mathrm{NH}_{4} \mathrm{Cl}, 41.5$ mM Na $2 \mathrm{HPO}_{4}, 22 \mathrm{mM} \mathrm{KH}_{2} \mathrm{PO}_{4}, 1 \mathrm{~mm} \mathrm{MgSO}_{4} \cdot 7 \mathrm{H}_{2} \mathrm{O}, 0.2 \mathrm{~mm} \mathrm{CaCl}$, and $0.1 \mu \mathrm{g} / \mathrm{ml}$ thiamine. Starvation medium (M9 buffer $+1 \%$ glucose $+10 \mu \mathrm{g} / \mathrm{ml}$ thymine) was used for preparation of amino acid starved E. coli. Minimum agar plates were made from medium 56 agar (see below) with addition of $2 \mathrm{~g} /$ liter glucose, $83 \mu \mathrm{g} / \mathrm{ml}$ DL-threonine, $83 \mu \mathrm{g} / \mathrm{ml}$ DL-leucine, $333 \mu \mathrm{g} / \mathrm{ml}$ L-proline, $0.17 \mu \mathrm{g} / \mathrm{ml}$ thiamine, and $17 \mu \mathrm{g} / \mathrm{ml}$ thymine. To measure survival of arg $^{-}$his ${ }^{+}$cells, we used minimum agar supplemented with $147 \mu \mathrm{g} / \mathrm{ml} \mathrm{L-arginine.} \mathrm{For} \mathrm{arg}^{+} h \mathrm{hs}^{-}$cells, we used minimum agar plates supplemented with $87 \mu \mathrm{g} / \mathrm{ml}$ DL-histidine. Medium 56 agar contains: $2.56 \mathrm{~g} /$ liter $\mathrm{KH}_{2} \mathrm{PO}_{4}, 4.25 \mathrm{~g} /$ liter $\mathrm{Na}_{2} \mathrm{HPO}_{4}$, $1 \mathrm{~g} /$ liter $\left(\mathrm{NH}_{4}\right)_{2} \mathrm{SO}_{4}, 100 \mathrm{mg} /$ liter $\mathrm{MgSO}_{4} \cdot 7 \mathrm{H}_{2} \mathrm{O}, 5 \mathrm{mg} /$ liter $\mathrm{Ca}\left(\mathrm{NO}_{3}\right)_{2}, 0.25 \mathrm{mg} /$ liter $\mathrm{FeSO}_{4} \cdot 7 \mathrm{H}_{2} \mathrm{O}$, and $1.5 \%$ Difco Bactoagar. L agar plates contain: $1 \%$ tryptone, $0.5 \%$ yeast extract, $0.05 \% \mathrm{NaCl}$, adjusted to $\mathrm{pH} 7.0$, and $1.5 \%$ Difco Bactoagar. Lambda buffer used for cell dilution was: $0.03 \mathrm{~m}$ Tris (hydroxymethyl) aminomethane- $\mathrm{HCl} \mathrm{pH} 7.2$ containing $0.05 \mathrm{M} \mathrm{MgSO}_{4} \cdot 7 \mathrm{H}_{2} \mathrm{O}$ and $0.25 \mathrm{~g} /$ liter gelatin.

\section{Effect of Bleomycin on Cells}

An exponentially growing culture of the test strain $\left(2 \sim 5 \times 10^{7} / \mathrm{ml}\right)$ was washed two times in cold M9 buffer at $4^{\circ} \mathrm{C}$ by low speed centrifugation, resuspended in cold buffer and held in ice until used.

Amino acid-starved bacteria were prepared by incubating exponentially growing cells for 60 minutes at $37^{\circ} \mathrm{C}$ in the starvation medium. Cells were exposed to bleomycin at $37^{\circ} \mathrm{C}$ for 10 minutes or $0^{\circ} \mathrm{C}$ for 30 minutes, then diluted 100 -fold in $\lambda$ buffer and plated on $\mathrm{L}$ agar, or minimum agar plates, as described in the figure legend.

\section{Effect of Gamma Rays on Cells}

Cells were prepared in exactly the same way as for treatment with bleomycin (see above). After suspension in the media as described in the caption to Fig. 1, they were warmed to $37^{\circ} \mathrm{C}$ and exposed at that temperature to $\mathrm{Co}^{60}$ gamma rays at $400 \mathrm{rads} / \mathrm{min}$ for $0 \sim 10$ minutes; after removal from the gamma ray source they were put in a $37^{\circ} \mathrm{C}$ bath and held there until the total time of exposure to gamma rays plus postirradiation incubation was 10 minutes (the time of incubation with bleomycin). They were then chilled until they could be dilated for assay for colony forming ability.

\section{Results}

In our hands, the action of bleomycin on E. coli cells was erratic, with substantial differences in the fraction of cells able to form colonies from exposure to the same amount of bleomycin under the same conditions in experiments done at various times. The sources of this irreproducibility are not known; we have found that $10^{-5} \mathrm{M}$ metal ions can increase (for $\mathrm{Co}^{++}, \mathrm{Fe}^{++}$) or decrease (for $\mathrm{Cu}^{++}, \mathrm{Zn}^{++}$) the amount of bleomycin needed, by factors up to 3 , to give the same decrease in colony forming ability of E. coli.

To obtain the most reproducible results, in most of our experiments the isogenic wild type and repair-deficient mutants were mixed in the same tube, treated together with bleomycin, and the effects of the bleomycin on each strain sorted out by the use of selective genetic markers. For example, from the strain AB2497 $\mathrm{rec}^{+} \mathrm{arg}^{-}$his $^{-}$, we selected spontaneous revertants AB2497-1 $\mathrm{arg}^{-} \mathrm{his}^{+}$and AB2497-2 arg $^{+}$his $^{-}$; from almost isogenic strain AB2487 recAl3 rrg-his $^{-}$, we prepared AB2487-1 arg $^{-}$his $^{+}$and AB2487-2 arg $^{+}{ }^{+}$his $^{-}$. When the two wild type strains were mixed together, treated with bleomycin and plated on selective agars, the sensitivities of the two substrains to bleomycin were identical; the same was true for the two rec $A$ strains (data not shown).

These strains have been used to show the effects of the physiological state of the cell on the action 
of bleomycin. Strain AB2497-1 $\mathrm{rec}^{+} \mathrm{arg}^{-}$his $^{+}$in exponential growth was mixed with AB2497-2 arg $^{+}$ his $^{-}$which had been starved for amino acids. They were treated with bleomycin in starvation medium with arginine (but not histidine) added, so that the cells in exponential growth phase grew exponentially, whereas the starved cells, lacking histidine, would stay in the starved state. The starved cells were much more resistant to bleomycin, having the same colony forming ability as exponentially growing cells treated with eight- to ten-fold more bleomycin (data not shown). This is in agreement with results

Fig. 1. The effect of bleomycin and gamma rays on mutant E. coli strains.

--- Strains, wild type in repair ability. - Strains, mutant in repair capability, as designated. Open symbols $(\bigcirc, \square, \diamond)$ cells in exponential growth. Filled symbols $(\bullet, \bullet)$ cells starved for amino acids for 60 minutes.

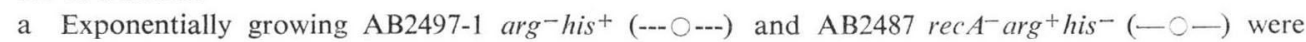

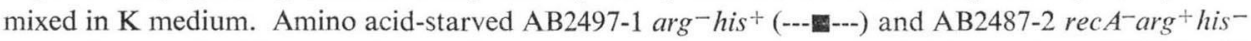
(一 - ) were mixed in starvation medium. Mixed cells were treated with bleomycin at $37^{\circ} \mathrm{C}$ for 10 min. Cells were plated on selective minimum agar after appropriate dilutions.

b Exponentially growing AB2497-1 his ${ }^{+}$(------) and amino acid-starved AB2587-2 recA his- (- were mixed in starvation medium with every needed amino acid except histidine, and exposed to

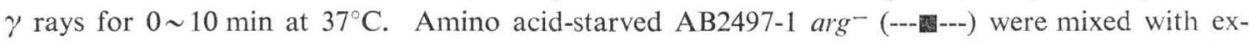
ponential $\mathrm{AB}_{2487-2} \mathrm{rec} A \mathrm{arg}^{+}(-\square-)$ in starvation medium containing all required amino acids except arginine, irradiated with $\gamma$ rays, and plated on selective agar.

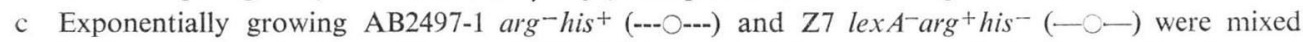

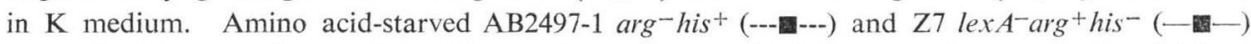
were mixed in starvation medium. Bleomycin treatment and plating were the same as Panel (a).

d The same as Panel (c) except the cells were irradiated with $\gamma$ rays.

e Exponentially growing $\mathrm{m} 147 \mathrm{polA}^{+}\left(----_{--}\right)$and $\mathrm{m} 22$ polA- (- - -) were suspended in $\mathrm{K}$ medium, each strain in a separate tube, and treated with bleomycin. Amino acid-starved m147 pol $A^{+}$ (----) and $\mathrm{m} 22 \mathrm{polA}^{-}(--)$were suspended in starvation medium, each strain in a separate tube, and treated with bleomycin. An appropriate dilution was plated on $\mathrm{L}$ agar.

f The same as Panel (e) except the cells were irradiated with $\gamma$ rays.
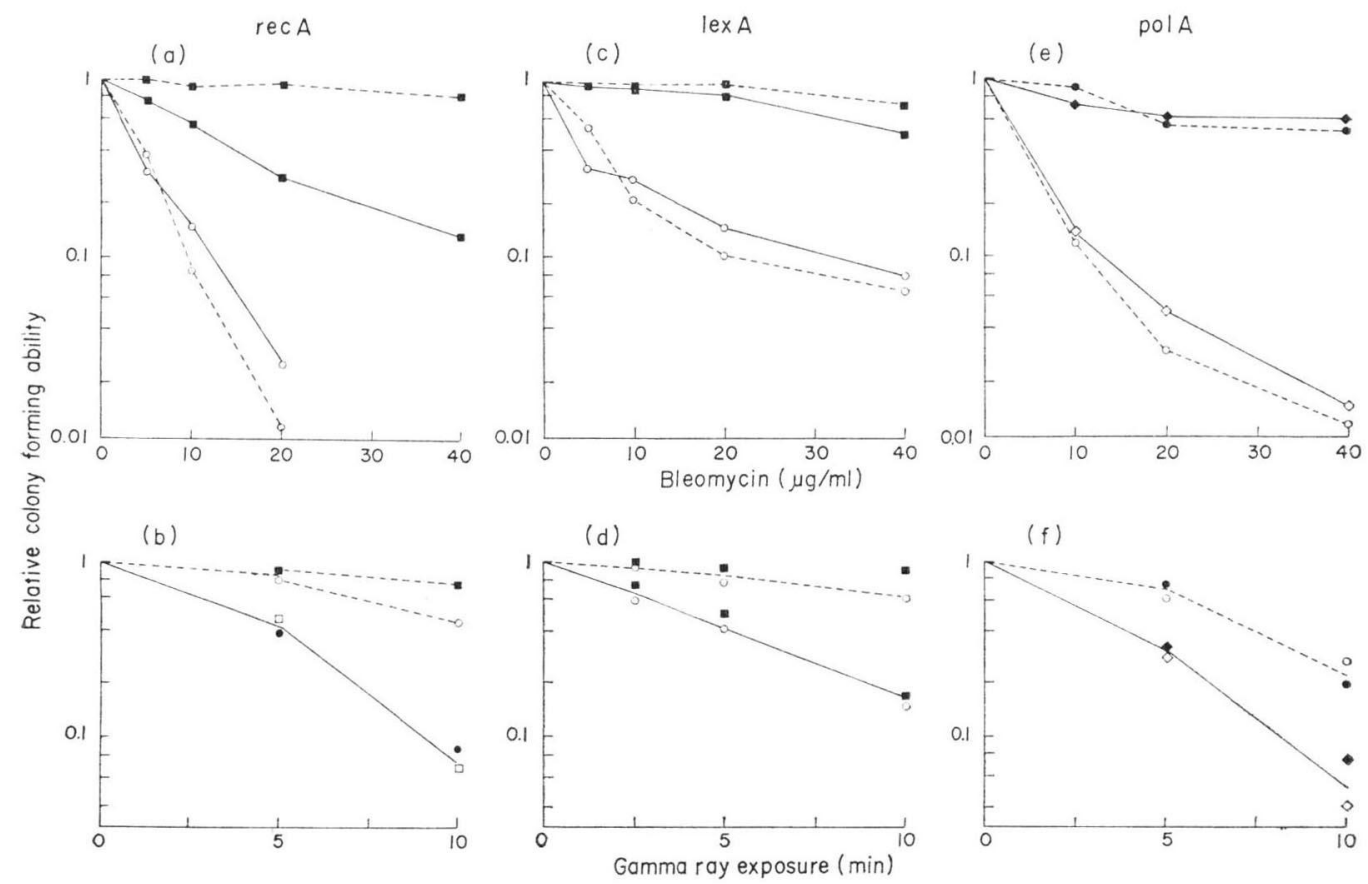
Table 1. Response of E. coli repair mutants to bleomycin and gamma rays.

\begin{tabular}{l|l|l|l}
\hline \multicolumn{1}{c|}{ Strain } & $\begin{array}{c}\text { Exponential cells } \\
\text { Exponential wild } \\
\text { type }\end{array}$ & $\begin{array}{c}\text { Starved cells } \\
\text { Exponential wild } \\
\text { type }\end{array}$ & $\frac{1}{\begin{array}{c}\text { Starved cells } \\
\text { Starved wild } \\
\text { type }\end{array}}$ \\
\hline AB2497 wild type & $1.0(1)$ & $8.0 \pm 2$ & $1.0(1)$ \\
AB2487 recA13 & $1.0 \pm 0.3(0.2)$ & $2.0 \pm 0.2(0.26)$ & $0.2 \pm 0.02(0.35)$ \\
Z-7 lexA1 & $1.0 \pm 0.3(0.15)$ & $7.2 \pm 3$ & $0.9 \pm 0.4(0.11)$ \\
m22 polA1 & $1.1 \pm 0.14(0.35)$ & $8.0 \pm 2$ & $1.0 \pm 0.2(0.46)$ \\
AB2500 uvr & $0.8 \pm 0.2(1)$ & $6.4 \pm 2$ & $0.8 \pm 0.2(1)$ \\
\hline
\end{tabular}

The unbracketed figure given in the Table is the amount of bleomycin which reduces the colony forming ability of the cell to the same level as does one unit of bleomycin acting on the wild type strain, either exponentially growing or starved for amino acids as shown. The figure in brackets is the experimental value for the gamma ray exposure of the mutant at $37^{\circ} \mathrm{C}$ which reduced colony forming ability to the same level as one unit of exposure of the wild type. Note that sensitivity to X-rays is the same for cells in exponential growth and starved for amino acids, so the bracketed figure for any particular mutant, i.e. rec A, should be about the same for all three columns.

previously published for the effect on $E$. coli cells not synthesizing protein of bleomycin ${ }^{15)}$, or phleomycin ${ }^{14,16}$. Starved AB2487 recA cells, however, had the same colony forming ability as exponentially growing $r e c A$ cells treated with only twice the amount of bleomycin.

If cells in exponential growth were treated with bleomycin in a medium lacking an essential amino acid, the curves of colony forming ability against bleomycin concentration tended to bend up, showing the presence of a resistant fraction, presumably cells going into a starved phase. Starved cells, treated with bleomycin in medium in which they could grow, developed a sharp initial drop in the survival curve, presumably from cells which had gone into growth during the bleomycin treatment.

Fig. 1 shows the effects of bleomycin on cells which are defective in DNA repair. In exponential growth, rec $A$, lexA and polA cells had the same sensitivity to bleomycin as did wild type cells. LexA and polA cells, starved for amino acids, responded to bleomycin as did starved wild type, but starved rec $A$ cells were about five-fold more sensitive.

Because of the similarities between many effects of ionizing radiations and of bleomycin as noted in the Introduction, the results for $\operatorname{rec} A$, lex $A$ and pol $A$ cells were puzzling. Therefore, $\operatorname{rec} A$, lex $A$ and pol $A$ mutant strains, together with the corresponding wild type strains, were exposed to gamma rays under conditions as nearly as possible those used for exposure to bleomycin (Fig. 1), instead of the usual conditions, $0^{\circ} \mathrm{C}$ in buffer. These results show that the mutants are all more sensitive to ionizing radiations than the corresponding wild type, and that, for each strain, cells in exponential growth have about the same sensitivity as those starved for amino acids.

The results of the experiments shown in Fig. 1, and of a number of other experiments for which the data are not given, are summarized in Table 1. The temperature at which the cells are exposed to bleomycin is important. For exposure at $0^{\circ} \mathrm{C}$ for 30 minutes, the colony forming ability of rec $A^{-}$cells is about four-fold more sensitive to bleomycin than is that of wild type, and cells in exponential growth have similar sensitivities to those which have been starved for amino acids (data not shown).

\section{Discussion}

The bleomycin results summarized in Table 1 are in good agreement with published reports except that of NAKAYAMA ${ }^{14}$. The responses of various repair mutants of $E$. coli to bleomycin clearly 
differ from those to ionizing radiations. It is possible that bleomycin acts on cell constituents other than DNA, but in view of the many similarities between the effects of bleomycin and X-rays, and the remarkable activity of bleomycin on DNA, such an hypothesis is not appealing. If the effects of both bleomycin and ionizing radiations are ascribed to DNA strand breaks and to bases released from the DNA, some significant difference in the two agents must be found. An obvious one is that the drug must pass through the cell wall to get to most of the cell DNA. YAMAGAMI, IsHIZAWA and ENDO ${ }^{17}$ ) found a mutant $E$. coli strain quite sensitive to bleomycin in which the exponentially growing $\operatorname{rec} A$ derivative is four-fold more sensitive than the $\mathrm{rec}^{+}$genotype; a bleomycin-resistant revertant had the same drug sensitivity for both the $\mathrm{rec}^{+}$and $\mathrm{rec} A$ derivatives. These authors suggested that the cell wall of the mutant might have increased permeability to bleomycin.

Our results and the difficulties expected in passing a molecule as big as bleomycin (molecular weight about 1,500 ) through a cell wall, suggest that much of the activity of bleomycin on bacteria may be from drug adsorbed to the cell wall acting on that part of the DNA attached to the wall. DNA damage near the replication fork, or confined to a very small part of the genome, may well act differently than damage from X-rays randomly distributed through the DNA.

\section{Acknowledgments}

The authors are grateful for discussion with Dr. Lawrence F. Povirk and Ms. Judith Stein. This research was supported by Grant CA 17938 from the National Cancer Institute, Department of Health, Education and Welfare.

\section{References}

1) Umezawa, H.; M. Ishizuka, K. Maeda \& T. Takeuchi: Studies on bleomycin. Cancer 20: 891 895, 1967

2) Ohama, K. \& T. Kadotani: Cytological effect of bleomycin on cultured human leukocytes. Jap. J. Human Genetics 14: 293 297, 1970

3) Onishi, T.; K. Shimada \& Y. Takagi: Effects of bleomycin on Escherichia coli strains with various sensitives to radiations. Biochim. Biophys. Acta 312: 248 258, 1973

4) Suzuki, H.; K. Nagai, H. Yamaki, N. Tanaka \& H. Umezawa: Mechanism of action of bleomycin. Studies with the growing culture of bacterial and tumor cells. J. Antibiotics 21: 379 386, 1968

5) Miyaki, M.; T. Kitayama \& T. Ono: Breakage of DNA-membrane complex by bleomycin. J. Antibiotics $27: 647 \sim 655,1974$

6) Haidle, C. W.; K. K. Weiss \& M. L. Mace, Jr.: Induction of bacteriophage by bleomycin. Biochem. Biophys. Res. Commun. 48: 1179 1183, 1972

7) Gudas, L. T. \& A. B. PardeE: DNA synthesis inhibition and induction of protein X in Escherichia coli. J. Mol. Biol. 101: 459 477, 1976

8) Shirakawa, I.; M. Azegami, S. Ishir \& H. Umezawa: Reaction of bleomycin with DNA strand scission of DNA in the absence of sulfhydryl or peroxide compounds. J. Antibiotics 24: $761 \sim 766,1971$

9) Povirk, L. F.; W. Wübker, W. KöHnlein \& F. Hutchinson: DNA double-strand breaks and alkalilabile bonds produced by bleomycin. Nucleic Acids Res. 4: 3573 3579, 1977

10) Müller, W. G. F.; Z. Yamazaki, H. J. Breter \& R. F. ZahN: Action of bleomycin on DNA and RNA. Eur. J. Biochem. 31: 518 525, 1972

11) Povirk, L. F.; W. Köhnlein \& F. Hutchinson: Specificity of DNA base release by bleomycin. Biochim. Biophys. Acta 521: 126 133, 1978

12) WARD, J. F. \& I. KUo: Strand breaks, base release, and postirradiation changes in DNA $\gamma$-irradiated in dilute $\mathrm{O}_{2}$-saturated aqueous solution. Radiation Res. 66: 485 498, 1976

13) Endo, H.: Qualitative difference between bleomycin and radiation effects on cell viability. J. Antibiotics 23: $508 \sim 510,1970$

14) Nakayama, H.: Phleomycin-induced lethality and DNA degradation in Escherichia coli K12. Mutation Res. 29: $21 \sim 33,1975$

15) Cohen, S. S. \& Josephine I : Synthesis and the lethality of bleomycin in bacteria. Cancer Res. 36: $2768 \sim 2774,1976$

16) GrigG, G. W.: Induction of DNA breakdown and death in Escherichia coli by phleomycin. Molec. Gen. Genet. 104: 1 11, 1969

17) Yamagami, H.; M. Ishizawa \& H. Endo: Phenotypic and genetic characteristics of bleomycin-sensitive strain of Escherichia coli. Gann 65: 61 67, 1974 